Received: December 22, 2017

Revision received: March 21, 2018

\title{
Application Research of E-learning Network Teaching Platform in College English Reading Teaching
}

\author{
Yiqun Qian ${ }^{1}$ \\ Changshu Institute of Technology
}

\begin{abstract}
With the development of multimedia technology networks, information technology is rapidly changing the production, work and lifestyle of human society. This change has also brought important influence to education. E-learning is an emerging product under this. At the same time, English reading is a very important part in college English teaching. E-learning plays a very important role in college English reading teaching in the new era. This paper will study this phenomenon, starting from the development of E-learning and its application in college English reading education, and propose a reasonable teaching method for the current English reading teaching mode and E-learning structure. Questionnaires and other methods have verified their effectiveness, pointing out the direction for further research.
\end{abstract}

\section{Keywords}

E-learning • English Reading Education • Online Education • College English

\footnotetext{
1 Correspondence to: Yiqun Qian (MA), Changshu Institute of Technology, Changshu 215500, China. Email: findakey@163.com
} 
With the rapid development of information technology, the emergence and widespread application of Internet has profoundly affected the development of society and economy, and changed people's thoughts, work, study and lifestyle (Johnson, Charchanti \& Troupis, 2012). The application of Internet technology has also triggered a revolution in education, and the whole society has entered a new era of E-learning (De-Marcos, Domínguez, Saenz-de-Navarrete \& Pagés, 2014).

The biggest difference between E-learning and traditional teaching is that the main body of traditional teaching is teachers. Knowledge flows from the "source" of teachers to students, and students are passive recipients of knowledge. In the E-learning environment, due to the openness and interactivity of the network, the center of teaching turns from the teacher to the student, and the student becomes the knowledge constructor of active learning. The transformation of such a teaching model makes the results of teaching, that is, the gains of students, be more dependent on the initiative of students' own learning. In this teaching process, teachers play a greater role in the organization, interpretation and transformation of information resources.

This study studies the application of E-learning in college English reading, analyzes its trial effect, and summarizes the effective strategies of E-learning in cultivating college students' English reading ability.

\section{E-learning}

Since the 1990s, with the increasing popularity of multimedia technology and the Internet, information technology is changing people's lives in all aspects. According to the US Department of Education's 2000 "Technical White Paper on Education" (Garcia-Cabot, de-Marcos \& Garcia-Lopez, 2015), E-learning refers to learning and teaching activities mainly through the Internet. It makes full use of the learning environment provided by modern information technology with new communication mechanisms and rich resources. A new way of learning is realized; this way of learning will change the role of teachers in traditional teaching and the relationship between teachers and students, thus fundamentally changing the structure of teaching and the nature of education.

\section{Structure of E-learning platform}

A Web-based E-learning system includes the following subsystem modules: user interface, student model, teacher model, test subsystem, knowledge base, test question library, etc. (Truong, 2016), as shown in Figure 1.

As shown in the figure, the user interface is a window for teaching and learning. The student completes the learning process through the user interface. The user interface provides various learning and communication platforms for students, including knowledge presentation, online communication, and online testing. The student model not only reflects the basic information of each learner, but also reflects the learner's knowledge and the mastery of the content that has already been learned, as the basis for future teaching. The teacher model 
stipulates the teaching content and teaching practice of the system, and the learner can choose independently. The test system includes tools such as test questions, and the students get an assessment of the learning status.

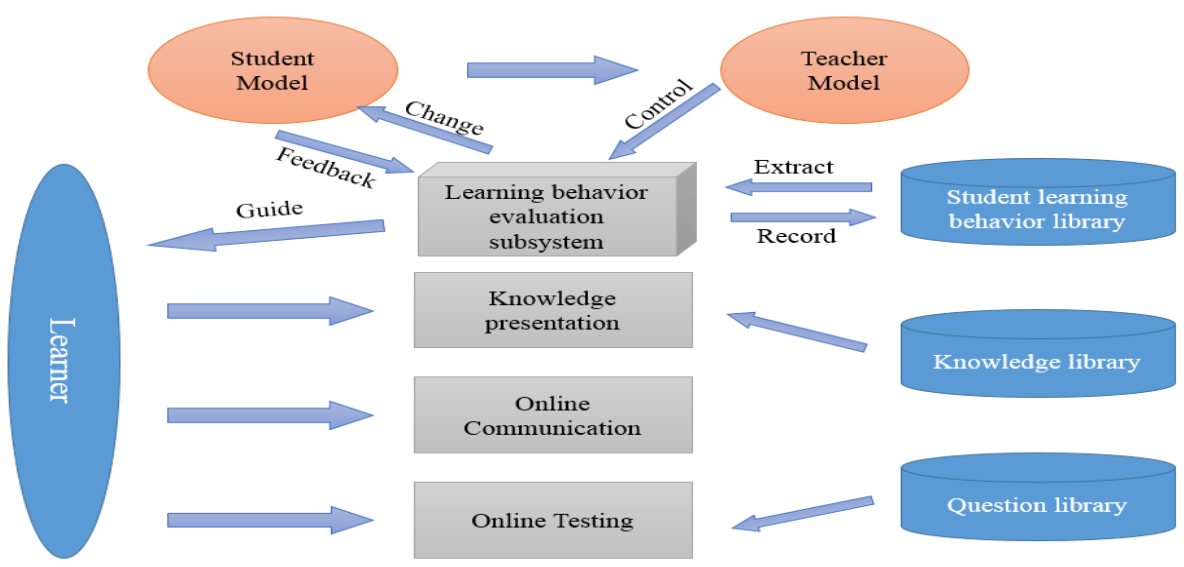

Figure 1. Web-based E-learning system.

\section{Learning behaviour in E-learning environment}

Learning in the E-1earning environment is highly autonomous learning. Teachers and students are in a state of relative separation of time and space. Without real-time monitoring and authoritative deterrence of teachers and students, learning can be completely dependent on students' learning motivation, self-awareness and selfcontrol. This puts high demands on the quality of the students themselves.

The various characteristics of e-learning determine that their learning evaluation has different requirements from traditional learning, and the summary is shown in Table 1.

Table 1

Network Learning Characteristics and Evaluation Requirements

\begin{tabular}{ll}
\hline Feature of E-learning & $\begin{array}{l}\text { Corresponding learning evaluation with a combination of digitization } \\
\text { and humanization }\end{array}$ \\
\hline Individual learning & $\begin{array}{l}\text { Continuous diagnostic evaluation, goal-based evaluation criteria, self- } \\
\text { evaluation }\end{array}$ \\
$\begin{array}{l}\text { Co-operating learning } \\
\text { Unstructured evaluation }\end{array}$ & Student mutual evaluation, group evaluation \\
Interactive learning & Unstructured task setup, multi-source evaluation technique \\
Learning through media & Learning behavior tracking, capturing evaluation information \\
technology & Digital and human integration \\
\hline
\end{tabular}

In addition, in order to ensure the success of learning, improve the learning effect and quality, the learning behavior control in the E-learning environment should be carried out, that is, the learning monitoring, the planning, checking, evaluation, feedback, control and adjustment of the learner's learning activities. A series of processes. 
Compared with developed countries, Chinese learners show many characteristics that are not suitable for Elearning environment, especially in the aspect of self-control, which is lack of autonomy, independence and self-learning ability. The measures taken are:

- Increase the participation of the teacher role in learning in the E-learning environment, and play the role of teachers in monitoring students;

- Develop students' self-learning ability and self-control ability;

- Externally impose other constraint monitoring mechanisms to impose certain external controls on learning.

\section{The Status Quo of College English Reading}

English reading is a process of complex individualized behaviour (Tang, 2016; Chen, Lu \& Liu, 2018). It is generally said that reading is defined as a selective process between readers and chapters. In this process, the reader's background knowledge and various linguistic knowledge communicate with the information in the text, and finally form an understanding of the chapter. For students, the specific performance is the comprehensive ability of students to apply English vocabulary, grammar and discourse (Sung, Hwang, Lin \& Hong, 2017; Putkinen, Tervaniemi, Saarikivi \& Huotilainen, 2015).

E-learning is mainly embodied in online learning in college students' learning. This section analyses and studies college students' English learning condition.

\section{Analysis of college students' English learning}

We used a questionnaire survey to investigate the English proficiency of 230 students. The results are shown in Figure 2.

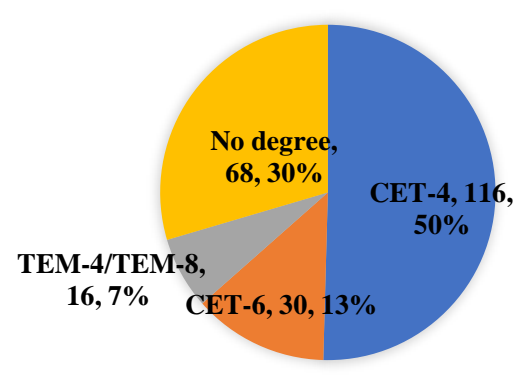

Figure 2. The English level of students.

It can be seen that the number of people passing the CET-4 examination accounted for $50 \%$, accounting for the vast majority, and many of the students who did not pass the CET-4 examination mostly had a small distance 
from the passing line. It can be seen that the difficulty level of CET-4 is in line with most students, and the selection of reading materials can be based on this.

In addition, we have statistics on the length of time that college students study English in their spare time. The results are shown in Figure 3.

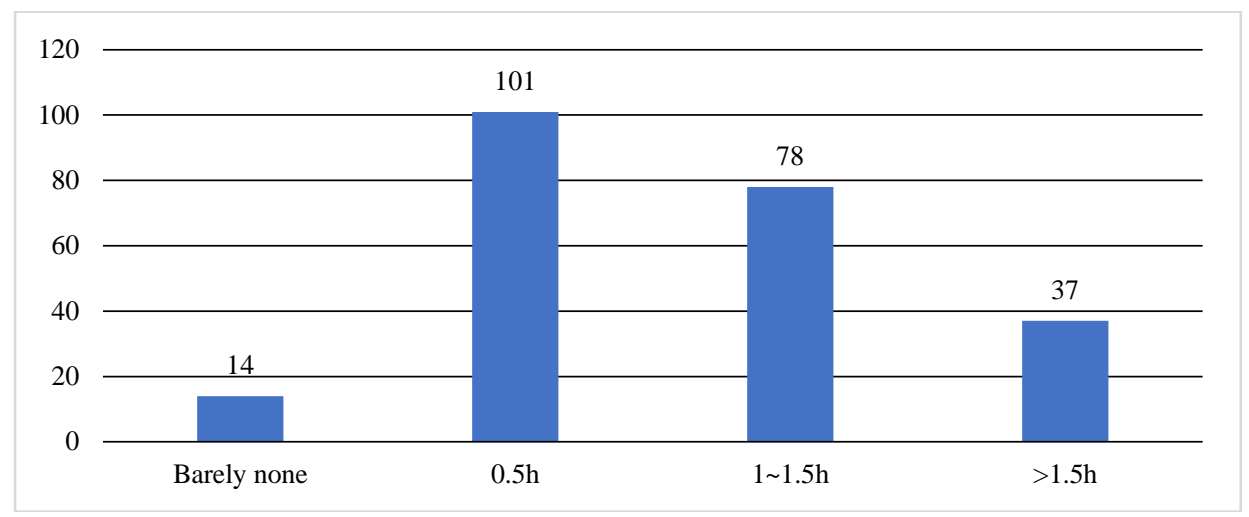

Figure 3. After-class learning time for English in college students.

It can be seen that most college students can spend 0.5 hours a day learning English. Few students spend almost no time on English learning. It can be said that the enthusiasm for learning English in college students is very high, and there is a certain basis for independent online learning.

\section{Investigation on college students' English learning habits}

For self-directed learning, the development of learning habits is very important (Ma, Steger, Doolittle \& Stewart, 2018). We conducted a survey of the habits of English reading exercises in the questionnaire. The results are shown in Table 2. It can be seen that more than half of the students can have a purposeful time limit in English reading, but only less than $15 \%$ of the students can perform limited time reading training each time, reflecting that most students do not have correct English reading habits. This phenomenon is widespread in university campuses, and this issue can be solved by the formal E-learning learning platform.

Table 2

Survey of College Students' English Reading Purpose

\begin{tabular}{lcccc}
\hline Purposeful reading and controlling reading time or not & Rarely & Sometimes & Usually & Every time \\
\hline Student number & 30 & 70 & 96 & 34 \\
Rate & $13 \%$ & $30.4 \%$ & $41.7 \%$ & $14.8 \%$ \\
\hline
\end{tabular}

At the same time, for the source of reading materials, as shown in Table 3, about half of the students choose English test papers for reading training, and less than $20 \%$ of students choose their favorite materials in the extracurricular books or websites. This book sequence also reflects the problem of most students' limited English reading. 
Table 3

College Students' English Reading Materials

\begin{tabular}{lccc}
\hline & Extracurricular articles & Articles from test papers & Articles from textbooks or teachers \\
\hline Number & 39 & 116 & 78 \\
Rate & $16.7 \%$ & $49.8 \%$ & $33.5 \%$ \\
\hline
\end{tabular}

\section{Application of E-learning in College English Reading}

As mentioned above, E-learning is to make full use of modern network technology, enrich teaching resources, change learning methods, learning content, teacher and student roles, and thus achieve a new type of teaching. Based on this theory, this study makes full use of modern online education technology, combines the current situation of reading teaching, and explores new modes and methods of reading teaching to improve the status of English reading.

This paper combines the E-learning network teaching platform with the university reading materials, and explores the English reading teaching mode based on the E-learning network teaching platform. Through empirical research, it proves that the model has strong promotion and operability. The teaching mode is shown in Figure 43.

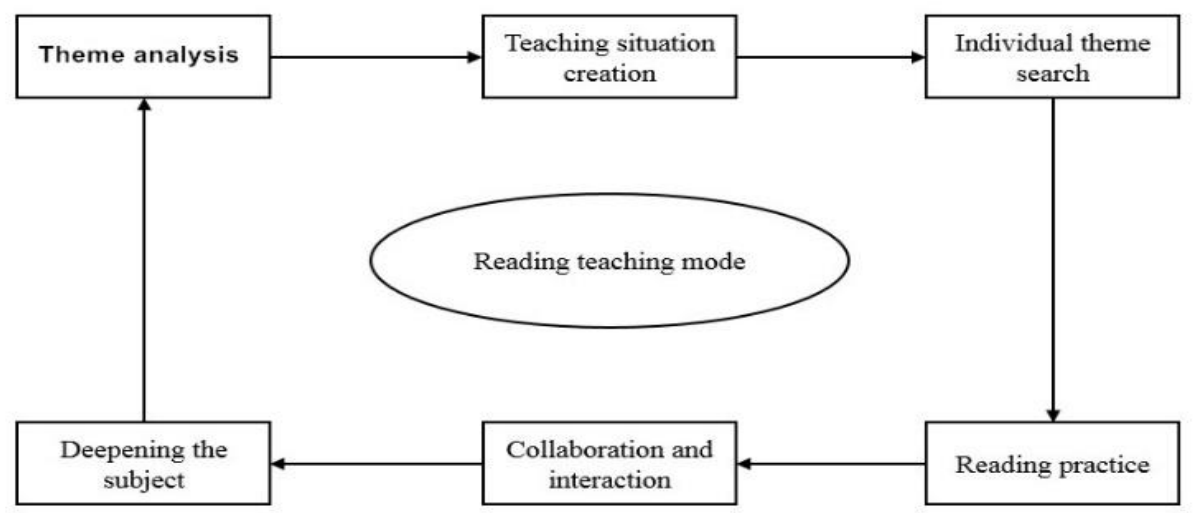

Figure 4. Reading teaching mode based on E-learning.

This teaching mode is designed to deepen the theme, broaden students' horizons and expand students' knowledge. At the same time, it guides students to contact themselves according to the theme, from the perspective of self, to think and further grasp the relevant knowledge of the topic.

After the platform is put into use for one semester, we use questionnaires to learn how to use the E-learning online teaching platform to learn and learn from the teaching design, teaching activities, and student learning. The teaching effect of the reading teaching mode of the network teaching platform is analysed and discussed. By analysing the teaching effect, we may improve the deficiencies in teaching, further optimize the teaching mode, improve the quality of online reading teaching, and provide an important reference for other scholars 
who use the E-learning network teaching platform for English teaching. The questionnaire is summarized as shown in Figure 5.

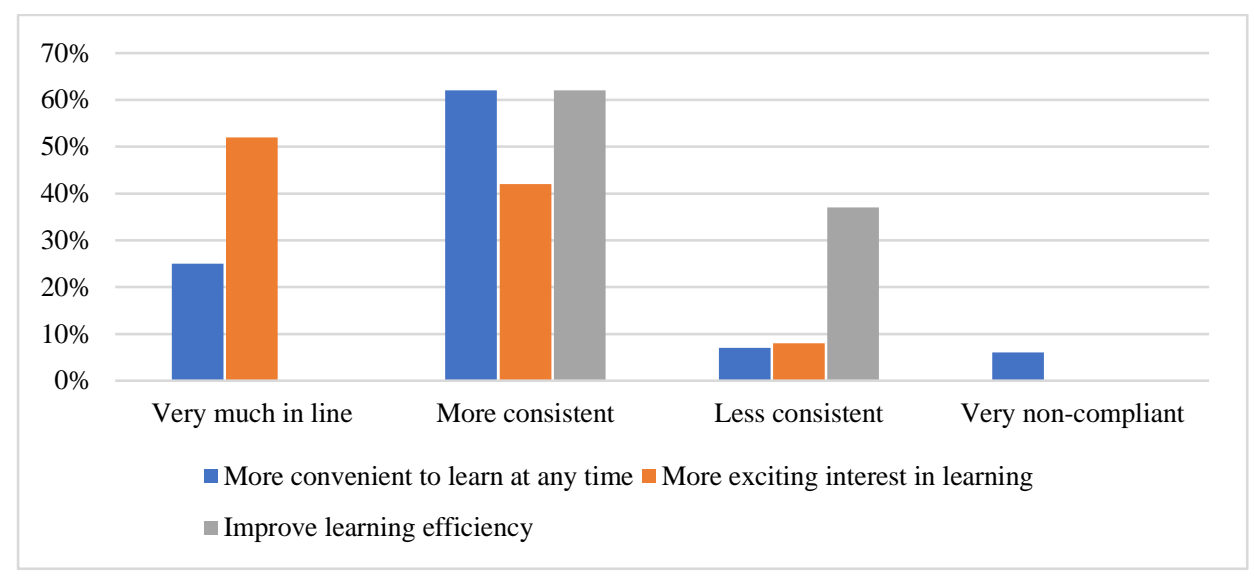

Figure 5. E-learning advantage survey.

As can be seen from Figure 5, most students believe that online teaching is more convenient than traditional English reading classes. With the development of the network, the coverage of wireless networks is now larger and larger, and students can learn through the network anytime and anywhere when network conditions permit.

And from the point of view of most students, the reading teaching model based on the E-learning network teaching platform is new, and students do not have to face boring book knowledge every day. Because students are more interested in new things, this teaching mode can stimulate students' interest in learning and enhance the interest of reading teaching, which is beneficial to students' active participation in activities and improve learning efficiency.

However, $37 \%$ of students still believe that online teaching is not conducive to improve learning efficiency, and no classmates agree that online classrooms are conducive to improving learning efficiency. This phenomenon deserves further exploration. From the horizontal comparison point of view, most students have affirmed the network reading classroom teaching, affirming the advantages of the online reading classroom compared to traditional teaching, which has significance for this research.

\section{Conclusion}

The purpose of this study is to explore the application effect of E-learning in college students' English reading courses, whether it is helpful to cultivate college students' English reading ability, improve college students' English reading level, and summarize the E-learning strategies suitable for college students' English reading ability training. Through the experiment, we investigate the application effect of E-learning in college English reading courses, and mainly draw the following conclusions: 
- At present, the overall level of English reading of college students is not high, and the reading level is average;

- E-learning is conducive to the establishment of lifelong learning concepts for college students and the promotion of independent learning for college students. It can stimulate students' interest to learn English, give play to the initiative and creativity of college students to learn English reading, and in a short period of time it is easier to improve college students' English reading ability.

- With the further popularization of wireless networks, the widespread use of E-learning in college English teaching will rapidly improve the English level of college students.

The goal of this study is to explore the effect of E-learning on English reading ability. E-learning can improve college students' English reading ability, but their English level is different. How to make use of Elearning to quickly locate the lack of reading ability and make reasonable methods of compensation has not been covered in this study, which continues to be of interest in future research.

In the future practical research, we will continue to improve the learning model of online English reading, make full use of advanced modern educational technology to make E-learning more in line with the English reading needs of college students, more convenient for college students to learn and effectively improve their English reading ability.

\section{References}

Chen, M.C., Lu, S.Q., \& Liu, Q.L. (2018). Global regularity for a 2D model of electro-kinetic fluid in a bounded domain. Acta Mathematicae Applicatae Sinica, English Series, 34(2): 398-403. http://dx.doi.org/10.1007/s10255-018-0740-3

De-Marcos, L., Domínguez, A., Saenz-de-Navarrete, J., \& Pagés, C. (2014). An empirical study comparing gamification and social networking on e-learning. Computers \& Education, 75, 82-91. http://dx.doi. org/10.1016/j.compedu.2014.01.012

Garcia-Cabot, A., de-Marcos, L., \& Garcia-Lopez, E. (2015). An empirical study on m-learning adaptation: Learning performance and learning contexts. Computers \& Education, 82, 450-459.

Johnson, E. O., Charchanti, A. V., \& Troupis, T. G. (2012). Modernization of an anatomy class: from conceptualization to implementation. a case for integrated multimodal-multidisciplinary teaching. Anatomical Sciences Education, 5(6), 354-366. http://dx.doi.org/10.1002/ase.1296

Ma, S., Steger, D. G., Doolittle, P. E., \& Stewart, A. C. (2018). Improved academic performance and student perceptions of learning through use of a cell phone-based personal response system. Journal of Food Science Education, 17(1), 27-32. https://doi.org/10.1111/1541-4329.12131

Putkinen, V., Tervaniemi, M., Saarikivi, K., \& Huotilainen, M. (2015). Promises of formal and informal musical activities in advancing neurocognitive development throughout childhood. Annals of the New York Academy of Sciences, 1337(1), 153-162. https://doi.org/10.1111/nyas.12656 
Sung, H. Y., Hwang, G. J., Lin, C. J., \& Hong, T. W. (2017). Experiencing the analects of Confucius: An experiential game-based learning approach to promoting students' motivation and conception of learning. Computers \& Education, 110, 143-153. https://doi.org/10.1016/j.compedu.2017.03.014

Tang, L. (2016). Exploration on cultivation of critical thinking in college intensive reading course. English Language Teaching, 9(3), 18. http://dx.doi.org/10.5539/elt.v9n3p18

Truong, H. M. (2016). Integrating learning styles and adaptive e-learning system: Current developments, problems and opportunities. Computers in Human Behavior, 55, 1185-1193. http://dx.doi. org/10.1016/j.chb.2015.02.014 